\title{
Pattern dynamics: an essay concerning principles, techniques, and applications ${ }^{1}$
}

\author{
L. Orlóci
}

\author{
Plant Sciences, University of Western Ontario, London, Canada N6A 5B7.E-mail: lorloci@julian.uwo.ca \\ Web address: sites.netscape.net/lorloci
}

Keywords: Arrangement, Chaos, Determinism, Epidemiology, Object, Order, Scale, Synmorphogenesis, Trajectory

Abstract. This Essay is response to the general question that I put to myself: How should I, an outsider to the topic, go about rationalising the notion of pattern and its dynamics when the pattern objects come from the vegetation? To facilitate succinct discussion of a very broad and intertwined topic, the Essay breaks down the pattern paradigm into three parts. The first part is concerned with the conceptual universe defined by the pattern objects, scale dependences, and order-chaos convolutions. The second part deals with the description of pattern and its evolution through time. The third, in the manner of a number of short comments, takes up pattern epidemiology, the Art of revealing cause and effect, extent, and significance.

\section{The conceptual universe}

\section{Pattern in general}

Broadly speaking, pattern is arrangement, concept allied with the notions of regularity, order, repetition, and scale. Since natural arrangements are dynamic, natural pattern is best regarded as a manifestation of complex dynamic processes at work. As for disciplinary interests, pattern is a main concern to all fields of natural science. Why? Much about Nature cannot be reasoned out from first principles. Patterns, physical or biological, have to be discovered by observation and described in precise terms before an understanding of natural phenomena can begin. Newton's answer to the puzzle "what is keeping planets in their orbit" could not have been given without access to a precise description of planetary motions. The seeing of an exact pattern came slowly through ages of cumulative experience - from the ancients through the Moors 8th -15th c., Copernicus 15th-16th c., Brahe 16th-17th c., and Galilei 16th-17th c. - until finally Kepler (16th-17th c.) got the thing right and Newton (17th-18th c.) could pinpoint the cause, gravity. The Darwin-Wallace theory of evolution (Darwin 1859) came from observation of reoccurring patterns in nature, and not just by themselves. Mendel's deduction of his statistical rule of particle-based inheritance (1870s) rested on observations that revealed a reoccurring pattern in his numbers. And Kerner's (1863) conception of the doctrine of plant community development by facilitation sprang from his discovery of reoccurring patterns in the ground arrangement of vegetation communities.

\section{Pattern objects}

Pattern objects define the nature of the pattern universe. Two extreme cases merit discussion:

\section{An engineer's universe}

In this, the objects are sharply drawn, and a blueprint exists. The blueprint makes perception and judgement unambiguous and independent of scale, facilitates reliable cost analysis in comparative terms, and allows accurate duplication. Such are not to be the characteristics of pattern universes at the other extreme, like those in the ecologist's case.

1 The Essay is based on a paper first presented at the UNIDO-ICS inter-disciplinary workshop on "The tools for understanding landscape patterns", organised by the Director and Program Consultant at ICS in co-operation with UNIDO and the Italian Ministry of Foreign Affairs. The workshop was held at the AREA Science Research Park in Trieste, September 20 - 22, 2000.

Terms used in the Essay, if not otherwise defined therein, should be understood in their colloquial sense, the first meaning, given in a better interpretive dictionary of the English language. 


\section{The ecologist's universe}

This universe is populated with fuzzy objects (Feoli and Zuccarello 1988 and references therein). Object fuzziness implies the lack of sharp demarcation and the arbitrariness of defining extent. An individual such as a plant of the rhizomatous sedge, Carex arenaria, or a vegetation stand within an area unit of arbitrary size are specific examples. Fuzziness imparts a unique characteristic to the ecological approach. E. C. Pielou called it "soft" and M. E. D. Poore described it "successive approximation". Furthermore, object fuzziness imprints fuzziness upon the expert's conclusions about pattern. The conclusions can never be a final utterance, but the outcome of synergistic growth through scale changes and information feedback. Process sampling (Orlóci and Pillar 1993) and flexible gradient analysis (Wildi and Orlóci 1991) are typical examples. In these, the conclusion emerges through continued expansion of the sample with the addition of new units or with changes in sampling unit size in steps. Sampling stops when some target structure, monitored every step of the way, reaches stability within arbitrarily set thresholds.

\section{Scale and effect}

"Ecology and plant geography are largely concerned with the causes of pattern at all scales" writes Peter GreigSmith (1983, p. 54). This emphasises the importance of scale. It is not difficult to go along with the proposition. One may even be justified to take a step farther, like Mandelbrot (1977) has done in his ponderings of form, and land surveyors has known all along, and accept that what is measured is a scale-dependent perception. If pattern is such a thing, it will have no more reality at one given scale than at any other. One thing must not be overlooked though. While each scale may present a different perception, the base-matrix of pattern, such as the patchy vegetation in a sand dune slack, is the same unique thing regardless differences in its perception.

Examples will help further to elaborate the scale effect and its manipulations:

\section{How long?}

Mandelbrots (1967) puts a simple question: how long is the British coastline? He concludes: it depends on the calliper width used to measure it. It appears longer when the calliper width is set smaller.

\section{How detailed?}

While length measurements gain precision with reduced calliper width, the reduction of sampling unit (pixel) size in an ecological survey may not guarantee clearer interpretations. The Africa map of Tucker, Townshend and Goff (1985) is a case in point. Reduction of detail by moving up to coarser scale is exactly the reason why we see the life-zones in the Africa map lined up like waves in a perfect cross-Africa pattern. Cartographers discuss the problem of how to get from too much detail to the right amount of detail to facilitate interpretation. The Africa map is obviously optimised for correlation with the continental climate and with the vegetation pattern the cartographers have known to exist. As for the life-zones, the "waves" analogy is quite appropriate, considering that these formations are in perpetual motion, assembling-dissembling-reassembling in a phenomenally synchronous manner with the changing environmental conditions, but with some considerable time lag. The changing composition and geographic position, or more specifically, changes in the state variables of the life-zone pattern, constitute pattern dynamics on the continental scale. This becomes apparent by simultaneous monitoring of dynamics at many pixels in time-precise interconnections.

\section{3. Éclat examples}

Perception of vegetation pattern is bound to be scale dependent. Good examples of this come from early treatments of the vegetation process (see Orlóci 2000 and references therein). These are generalisations largely concerned with the epidemiology of the process at specific levels of resolution:

a. Dominance sorting. The observer who uses narrow time steps within a short time period, a common research mode in site-level studies of dynamics and its controlling mechanisms, is more than likely to arrive at the epidemiological conclusion that the core vegetation process is local dominance sorting. It is pre-ordained that tolerance and inhibition (Connell and Slatyer 1977), life history type (Grime 1977), cohort senescence (Mueller-Dombois 1992), reproductive strategies (Harper 1977), and propagule bank composition (Egler 1954) come to the fore of attention as main causal mechanisms.

b. Facilitation. When the time step is left wide, and the period length does not exceed the longevity of an essentially stable climate, facilitation (also known as action-reaction feedback) will appear as the dominant causal mechanism. Facilitation is typically the level at which community development is interpreted by Kerner (1863) and by all the ecological throngs that came after him in the early parts of the $20^{\text {th }}$ Century. The interpretations rely largely on surrogate time series. Such series are constructed on the basis of what is called space-for-time substitution (Wildi and Schütz 2000). 


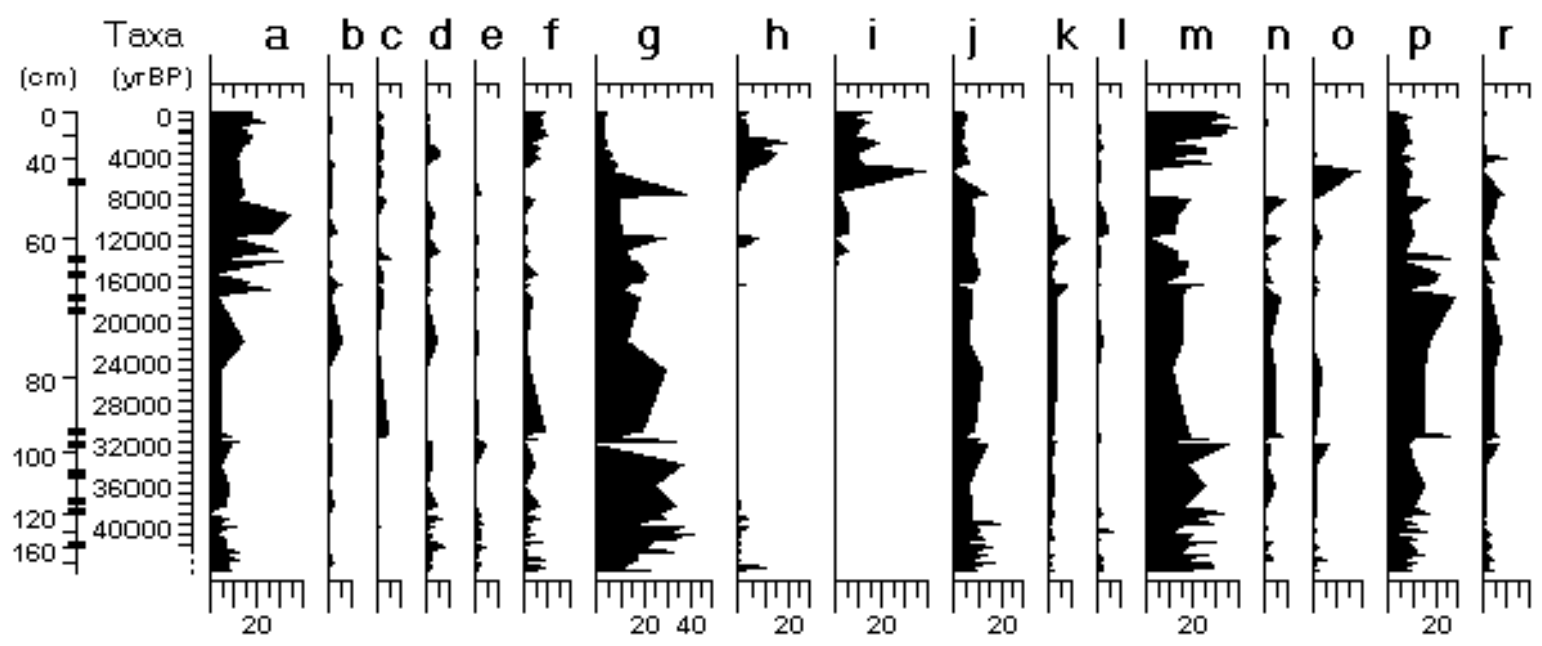

Figure 1. The De Oliviera paleopollen spectrum copied from website: http://www.ngdc.noaa.gov/cgi-bin/paleo/poldgma.cgi?handle=DASPATAS Site Name: Lagoa das Patas Contact: De Oliveira, P.E.; Place: BRA, Amazonas; Lat/Lon: $0.3^{\circ} \mathrm{N} / 66.7^{\circ} \mathrm{W}$; Altitude (m): 300; Samples/Variables/Dates: 49/179/12; Age Range: 0-42210. Legend to taxa and groups of taxa: a - Alchornea/Aparisthmium; b - Aquifoliaceaec; c - Arecaceae (excluding Mauritia); d - Caesalpiniaceae undiff.; e - Cassia; f - Cecropia; g - Combretaceae/Melastomataceae undiff.; h - Copaifera; e - Mauritia; j - Myrtaceae; $\mathrm{k}$ - Podocarpus; 1 - Tapirira; $\mathrm{m}$ - Urticaceae/Moraceae; $\mathrm{n}$ - Fabaceae; o - Poaceae; $\mathrm{p}$ - Other trees and shrubs; $\mathrm{r}$ Other herbs.

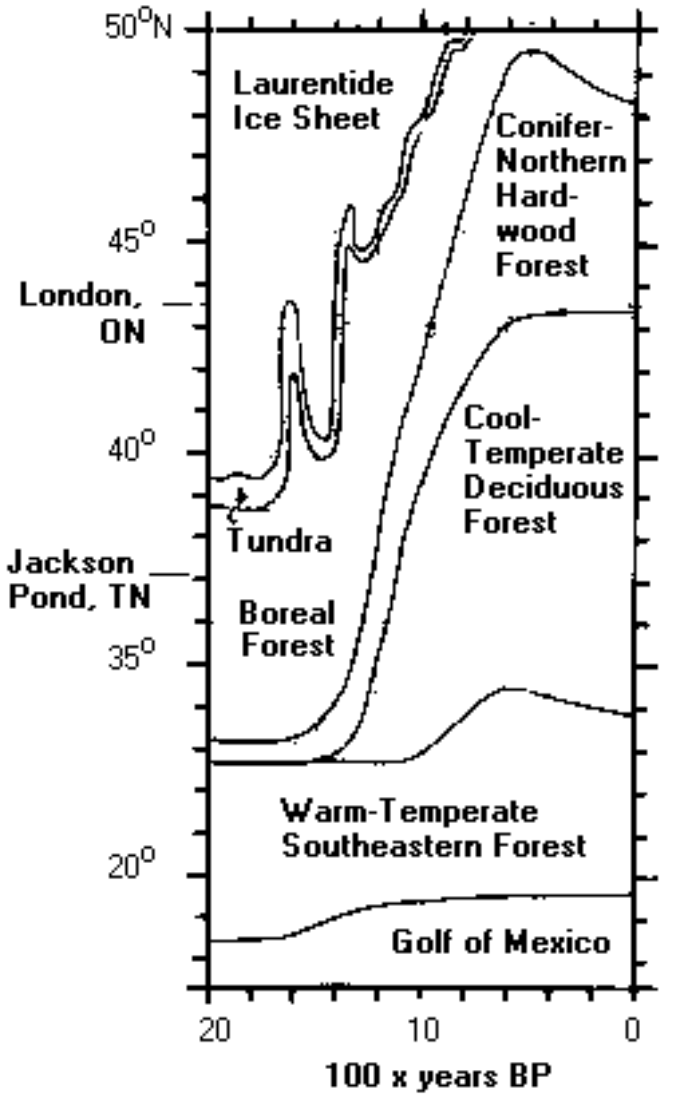

Figure 2. Global attractor migration in the Late Quaternary on latitude $\sim 85^{\circ} \mathrm{W}$ in eastern North America. Graph after Delcourt and Delcourt (1987, Fig. 1.4, p. 20), modified. Vertical scale: northern latitude. Horizontal scale: time before present. c. Precession dynamics. Community dynamics has aspects that only a one-way response to planetary climate change could explain under celestial causes. One of these, the precession of the equinoxes (Milankovitch 1941), contributed to the coining of the term "precession dynamics" to identify a high-level vegetation process. Precession effects can be detected when the process is viewed in the reflections of paleopollen spectra where the period length is very wide. The set of measured (not the interpolated) points in the Lagoa das Patas spectrum (Figure 1) is a good example. The picture that Delcourt and Delcourt (1987) have drawn about vegetation dynamics (Figure 2) is rich in indications. Zonal vegetation shifts are the result across latitudes north and south.

It should be emphasised that dominance sorting, facilitation, and precession dynamics are not isolated kinds of processes. They are different perceptions of a single, unified process under changes of magnification. Their isolation is analytical and an entirely arbitrary manoeuvre, but not superfluous. Through isolation of components vegetation dynamics can be measured.

Order in chaos or chaos in order? - a question put to G. P. Patil

Bartlett (1975, p. viii) contrasts pattern with what he calls "complete random chaos." But questions arise when one tries to translate Bartlett's phrase into an operational 
definition intended for use in studies of vegetation. This fact warrants the following discourse.

\section{What to include?}

If the individual terms in Bartlett's phrase are taken in their colloquial sense, first definition that comes up in interpretive dictionaries, then it is justified to exclude arrangements from under the concept of pattern that are lacking contagion or contiguity. In other words, pattern could mean that chance does not rule. But this is not the meaning that standard ecological texts use. Greig-Smith (1983) takes the complete random arrangement as a type of "pattern" and uses it as a reference arrangement to which observed cases of are compared.

\section{The "chaos" confusion}

As regards the term "chaos", the discrepancy with colloquial usage is often very acute. In the technical jargon of the Art, things deteriorated to the point that the common sense meaning of "chaos" as "complete disorder" or "complete confusion" is replaced with something quite different. This started probably as an accidental glitch in the usage of the English language that forced upon "chaos" the totally unnatural meaning "... an apparent disorder owing to apparent random changes as a result of extreme sensitivity to small differences in initial conditions ...". The reader, exclaiming "What a gobbledygook!" is forgiven.

Ambiguities to be avoided, I am returning to the colloquial meaning of terms in the essay when I speak of "chaos infested determinism", "random distorted Markov chain", "convolution of chaos and determinism", initial conditions", or just simply use "chaos" or any of the others on their own.

\section{Examples}

The following narrative should throw further light on the notions while further highlighting to the reader the terminological dilemma:

a. Perrin's Brownian trajectories. Each irregular line in Figure 3 is the tracking of a colloidal particle (radius 0.53 $\mu \mathrm{m})$ in stable fluid as seen in a portion well inside a microscope's viewing field. The particle's position is marked at every 30 seconds. A direct interpretation of the tracks in the $20 \times 25$ grid would make little sense, considering the certainty that they would look totally different if recorded on film with a fast rolling camera over the same period of time. On film, the colloidal particle would most likely appear zigzagging the entire field of view. Each grid cell would be visited by the particle with increasingly

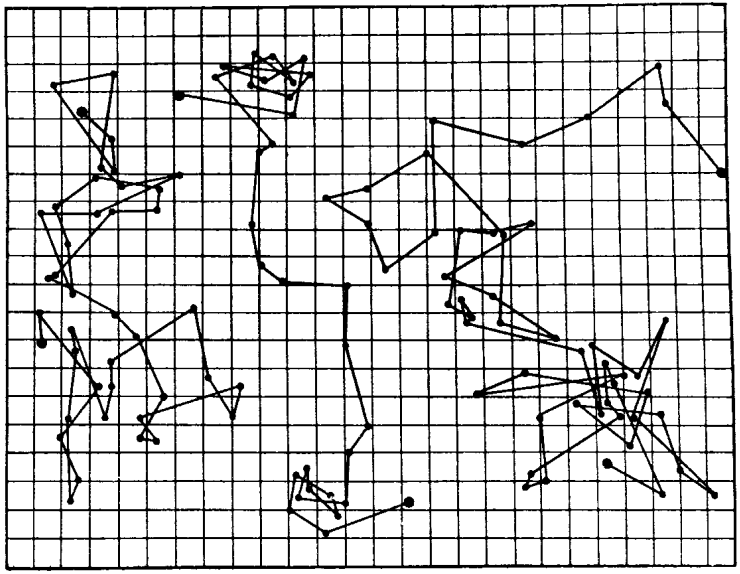

Figure 3. Brownian trajectories. Grid size: $3.2 \mu \mathrm{m}$ (after Perrin 1913).

equal frequency. After hours of recording the particles totally unconstrained motion would be generating a frequency distribution for which Rényi's (1961) entropy of order one $(8.965 \ldots$ bits) would signal that Bartlett's "complete random chaos" is reached. But the plan of motion lacking any particular rule, except the equal probability law, "complete random" or "complete disorder" is quite sufficient as a characterisation. If one puts it this way: the next cell to be visited is indefinite, while the probability of every cell is definite, then one sees that one described a case of "stochastics". In still other words, order in the form of an equidistribution is imposed on chaos, for whatever epidemiological reasons.

b. E. C. Pielou's L-mosaic. The mosaic in Figure 4 is constructed with lines drawn at random points in random directions. Shades indicate cells that are occupied or left empty by a given species. I added the heavy line to emulate an east-west "vegetation transect". Although the lines are drawn at random, the presence of order is striking. It appears in the form of a stochastic regularity, the probability distribution of which is given by

$f(d)=\lambda e^{-} \lambda^{d}$

(see Pielou 1977, p. 188; also Bartlett 1975, pp. 47-48). Symbol $d$ represents cell width (inter point distance on transect). $\lambda$ is the regularity constant, i.e., the number of intersection points per unit length of line transect. What would happen if line density were increased? Surely, cell size would shrink, and in the extreme $d$ would tend to zero. This is another case of stochastics, and once again chaos is producing order.

Pielou's (1964) work on the L-mosaic is in part an exercise in pattern identification. How was the sampling done? Circular quadrats (diameter $2 \mathrm{~cm}$ ) were laid in a transect in pairs at $s=2,4, \ldots, 12$ $\mathrm{cm}$ apart and the quadrat types were recorded in the manner of Ta- 


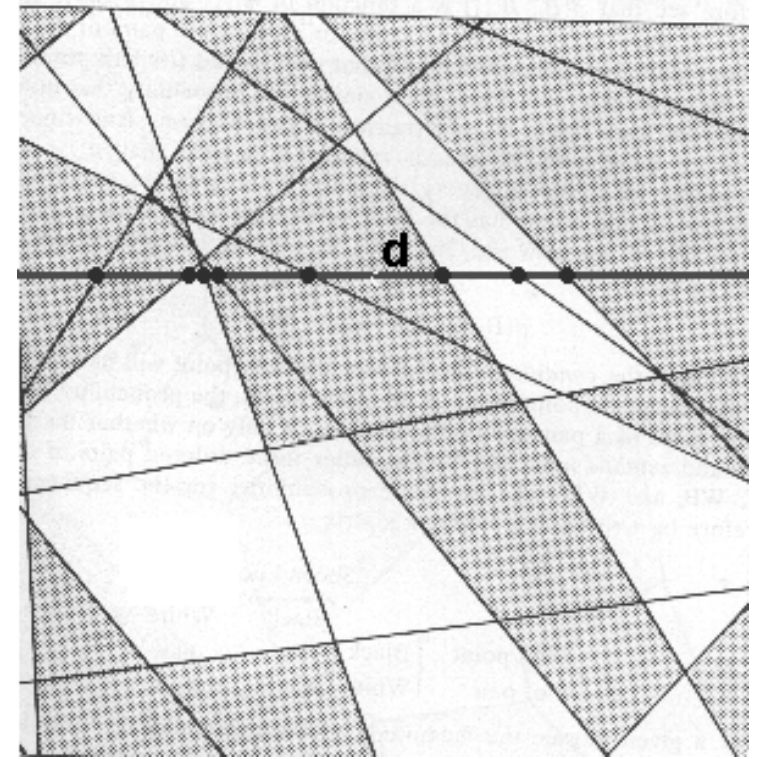

Figure 4. L-mosaic. After Pielou (1977, p. 183).

Table 1. Data recording in Pielou's L-mosaic (see the text for explanations.)

\begin{tabular}{lccc}
\hline Type of first quadrat & \multicolumn{2}{c}{ Type of second quadrat } \\
& vegetation & $\begin{array}{c}\text { Total } \\
\text { no } \\
\text { vegetation }\end{array}$ & \\
\hline Vegetation & $a_{11}$ & $a_{12}$ & $a_{1}$ \\
No vegetation & $a_{21}$ & $a_{22}$ & $a_{2}$ \\
Total & $a_{1}$ & $a_{2}$ & 1 \\
\hline
\end{tabular}

Table 2. Pielou's data. See the text for details and also Bartlett (1975, p. 48).

\begin{tabular}{ccc}
\hline $\mathrm{s}$ & $\mathrm{R}_{\mathrm{ts}}$ & $e^{-\lambda s}$ \\
\hline $2 m$ & .75 & .78 \\
4 & .64 & .61 \\
6 & .46 & .48 \\
8 & .27 & .37 \\
10 & .41 & .29 \\
12 & .32 & .23 \\
\hline
\end{tabular}

ble 1. Having had such data, Pielou computed the autocorrelation coefficient in the manner of $R_{t s}=\left(a_{11}-a_{1}^{2}\right) / a_{1} a_{2}$. In repeated trials with quadrat pairs at the given distances apart, the estimator $R_{t s}$ turns out to be tending in value in order terms to the exponential $e^{-}$ $\lambda s$ (see Table 2). The question arises: is it reasonable to suggest that pattern at the given scale is an L-mosaic? It could be that, but to be convinced the same expectation should hold true for the autocorrelation in any transect laid down at random anywhere in the site. If pattern is in fact an L-mosaic then the generating process is Markovian (see Bartlett 1975, p. 49) with constant probability $\mathrm{p}_{1}$ when switching from vegetation patch to bare ground, and with constant probability $\mathrm{p}_{2}$ when switching back. Obviously, the model is not very practical and probably it is never fulfilled to satisfaction in nature. a

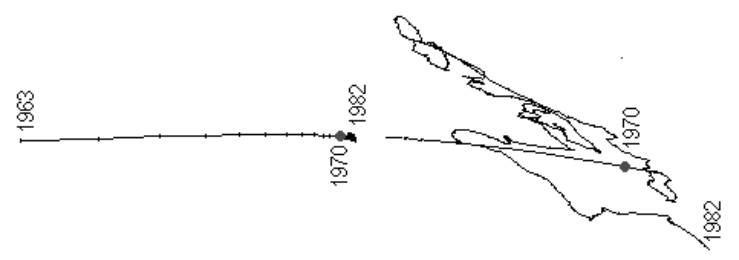

b
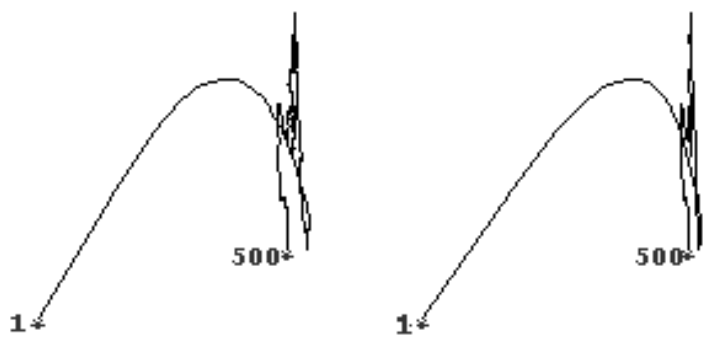

Figure 5. Eigenmap of the random-perturbed Markov chain fitted to the Atlantic Heathland data in Table 3. Left graph of $5 \mathrm{a}$ is drawn to scale. In right graph of 5a and in the stereogram image $(5 b)$ ranges are set equal on the axes for clearer viewing.

b. Perturbed Markov trajectory. It is clear that order arises in chaos intrinsically in the form of stochastic regularities. It is easy to shown that chaos can infest order. Some refers to this the case of the "fractal". To see this point, it should be sufficient to think of May's (1976, May and Oster 1976) experiments with the logistic equation, or even simpler, to consider the trajectories portrayed in Figure 5. In the latter, random perturbation is applied to the transition probabilities in sweeps through the entire transition probability matrix at every step in the process as the chain is computed. The level of perturbation is 0 to $1 \%$ at any step. The level and sign, whether positive or negative, depends on a flat probability law ${ }^{2}$.

Further comments are in order. The 1st dimension in Figure 5 accounts for $98 \%$ of the total variation. The trajectory length is 19 years. The fitted Markov chain's period length is 500. It is seen that severe occlusion develops at about the 13th Markov step (7th year into the real process). At that point the sites carrying capacity is reached and the trajectory enters a stage of turbulent oscillations. It will be seen in the sequel that this pattern mimics nature well. Observe Figure 5a in which a portion of the trajectory is enlarged, and note the alternating linear and non-linear phases. Orlóci and Orlóci (1988, Orlóci, Anand, and He 1993, Anand and Orlóci 1997) suggest on this basis that syndynamics in the site is probably a random-perturbed (chaotic) Markov chain. Some may rejoice hearing this in the hope of possible Markov predictions. But that may not work out, as expected. The uncertain time of entrance into and exit out out of turbulence, and the uncertain direction in which the proc-

2 Here referring to pseudo random numbers with equal probability. 
Table 3. De Smidt's cover estimates (Lippe et al. 1985) from annual surveys of an Atlantic Heathland site. Explanation of symbols: BG - bare ground; EN - Empetrum nigrum; CV - Calluna vulgaris; ET - Erica tetralix; MC - Molinia caerulea; RA - Rumex acetosella; JS - Juncus squarrosus; CP - Carex pilulifera; OS - other species (as per original records).

\begin{tabular}{lccccccccc}
\hline Year & BG & EN & CV & ET & MC & CP & JS & RA & OS \\
\hline 1963 & 57.1 & 17.9 & 8.60 & 11.6 & 0.0 & 0.2 & 0.0 & 4.7 & 0.0 \\
1964 & 44.0 & 25.0 & 13.7 & 12.2 & 0.0 & 1.1 & 0.2 & 3.9 & 0.0 \\
1965 & 32.7 & 34.9 & 13.9 & 14.3 & 0.0 & 0.5 & 0.0 & 3.7 & 0.0 \\
1966 & 27.5 & 36.8 & 20.0 & 14.1 & 0.1 & 0.9 & 0.2 & 0.3 & 0.1 \\
1967 & 19.7 & 46.1 & 21.0 & 10.8 & 0.1 & 0.7 & 0.4 & 0.5 & 0.7 \\
1968 & 10.7 & 54.2 & 22.2 & 10.6 & 0.7 & 0.6 & 0.4 & 0.0 & 0.5 \\
1969 & 6.70 & 55.7 & 23.3 & 10.4 & 0.3 & 2.0 & 0.7 & 0.1 & 0.7 \\
1970 & 5.80 & 61.1 & 23.7 & 6.90 & 0.2 & 1.2 & 0.7 & 0.2 & 0.3 \\
1971 & 9.50 & 57.6 & 24.7 & 6.60 & 0.4 & 0.6 & 0.4 & 0.0 & 0.3 \\
1972 & 8.40 & 62.1 & 23.7 & 3.60 & 0.3 & 1.2 & 0.1 & 0.0 & 0.6 \\
1973 & 4.40 & 67.9 & 21.3 & 3.30 & 0.2 & 0.6 & 0.4 & 0.0 & 2.0 \\
1974 & 8.50 & 58.1 & 25.8 & 4.70 & 0.6 & 1.3 & 0.7 & 0.0 & 0.4 \\
1975 & 9.20 & 62.2 & 24.3 & 2.50 & 0.6 & 0.9 & 0.2 & 0.0 & 0.1 \\
1976 & 9.90 & 58.2 & 24.9 & 3.70 & 0.6 & 1.1 & 0.7 & 0.0 & 1.0 \\
1977 & 19.6 & 48.4 & 23.5 & 5.70 & 0.3 & 1.2 & 0.4 & 0.1 & 0.9 \\
1978 & 12.1 & 58.1 & 22.7 & 4.80 & 0.4 & 0.4 & 0.0 & 0.2 & 1.3 \\
1979 & 9.30 & 65.1 & 20.3 & 2.70 & 0.0 & 1.5 & 0.1 & 0.2 & 0.9 \\
1980 & 7.30 & 68.2 & 21.5 & 1.20 & 0.5 & 1.0 & 0.1 & 0.1 & 0.2 \\
1981 & 5.40 & 65.5 & 20.8 & 4.60 & 1.0 & 1.6 & 0.4 & 0.3 & 0.6 \\
\hline
\end{tabular}

ess will be heading upon exit will make any prediction a chancy proposition.

Another point takes the reader back to Perrin's graphs. The graphs of Figure 5 have similarity with Perrin's (Figure 3), but there is a big difference. The process in the Atlantic Heathland plays itself out in nature under severe biological and environmental constraints. This is unlike the colloidal particle's homogeneous stable fluid environment.

\section{Corollaries}

There are three main points to be made to round out what has already been said about the basic character of pattern:

a. Bartlett's complete random chaos. Vegetation pattern cannot exist in a state that Bartlett called "complete random chaos". The vegetation trajectory cannot be Brownian. This is because the causes that make for order and directedness are always present intrinsically and extrinsically. The reader should find A. S. Watt (1947) good reading on a related topic.

b. Pure order. Vegetation pattern cannot exist in a state of pure order. This is because the causes that tend to undermine order and promote chaos are also present. This is the basic mechanism that drives variation and evolution.

c. Chaos infested order. Vegetation pattern must exist in a mixed state, but mainly as a "chaos infested order". This is a potent way in its consequences that make the immediate future very uncertain, but leaves the "long run" still predictable with some confidence from past events on scales that I am considering here.

\section{A practical consideration}

Whatever way one looks at it, chaos is an integral part of nature. It cannot be removed from pattern analytically by simply removing portions of the total variation that does not fit some stipulated model of order. Two things are important:

i) The residuals that do not fit a given model of order most probably contain components that would be judged orderly under some other model of order.

ii) What happens when residuals are thrown away as is normal practice in technician level biometry? The analysis will do no better in consequence than giving the interpretation of a mutilated data structure.

\section{Making sense of pattern}

\section{Analytical scenario}

A specific analytical scenario may be built about any objective, yet the main steps in the analysis will remain the same: pattern detection, pattern description, epidemiology. Two extreme cases are mentioned that set broad limits on the scenario:

\section{Type of pattern specified}

A specific kind of spatial pattern is expected, specific to structures blurred by the interference of noise. This is 
Table 4. State variables and scale variables.

\begin{tabular}{|c|c|c|c|}
\hline Author & State variable & $\begin{array}{l}\text { Scale vari- } \\
\text { able }\end{array}$ & $\begin{array}{l}\text { What is defined or } \\
\text { sought? }\end{array}$ \\
\hline $\begin{array}{l}\text { Kershaw (1973, Fig. } \\
\text { 8.10. p. 155) }\end{array}$ & $\begin{array}{l}\text { Correlation of species } \\
\text { and an } \\
\text { environmental } \\
\text { variable. }\end{array}$ & $\begin{array}{l}\text { Block size } \\
2,4,6, \ldots\end{array}$ & $\begin{array}{l}\text { Block size effect on } \\
\text { correlation. }\end{array}$ \\
\hline $\begin{array}{l}\text { Greig-Smith (1983, } \\
\text { Fig. 20, p. 98) }\end{array}$ & Mean square. & $\begin{array}{l}\text { Block size } \\
2,4,6, \ldots\end{array}$ & $\begin{array}{l}\text { Block size effect on } \\
\text { departure from } \\
\text { random expectation. }\end{array}$ \\
\hline $\begin{array}{l}\text { Orlóci (1971, Fig. 1, } \\
\text { p. 348) }\end{array}$ & $\begin{array}{l}\text { Information } \\
\text { theoretical quantities, } \\
\text { mean square. }\end{array}$ & $\begin{array}{l}\text { Block size } \\
2,4,6, . .\end{array}$ & $\begin{array}{l}\text { Block size effect upon } \\
\text { state variable. }\end{array}$ \\
\hline $\begin{array}{l}\text { Bartha, Czárán, and } \\
\text { Podani (1998, Fig. 2, } \\
\text { p.55) }\end{array}$ & $\begin{array}{l}\text { Juhász-Nagy's co- } \\
\text { existence relations. }\end{array}$ & Plot size. & Plot size effect. \\
\hline $\begin{array}{l}\text { Podani, Czárán, and } \\
\text { Bartha (1998, Fig. 5, } \\
\text { p. 108) }\end{array}$ & $\begin{array}{l}\text { Probability of species } \\
\text { co-occurrence. }\end{array}$ & Plot size. & Plot size effect. \\
\hline $\begin{array}{l}\text { Fekete \& Fekete } \\
\text { (1998, Fig. 4, p. 33) }\end{array}$ & $\begin{array}{l}\text { Distance density } \\
\text { function. }\end{array}$ & $\begin{array}{l}\text { Point pair } \\
\text { distance. }\end{array}$ & Patch interactions. \\
\hline $\begin{array}{l}\text { Orlóci \& Orlóci } \\
\text { (1990, Fig. 3, p. 317) }\end{array}$ & $\begin{array}{l}\text { Sum of square, angle, } \\
\text { distance. }\end{array}$ & $\begin{array}{l}\text { Location } \\
\text { on the } \\
\text { transect. }\end{array}$ & Edge detection. \\
\hline $\begin{array}{l}\text { Scheuring (1993, Fig. } \\
\text { 1, p. } 72)\end{array}$ & $\begin{array}{l}\text { Hausdorff (fractal) } \\
\text { dimension of a } \\
\text { graph. }\end{array}$ & $\begin{array}{l}\text { Calliper } \\
\text { width. }\end{array}$ & $\begin{array}{l}\text { Fractal dimension of } \\
\text { pattern graphs. }\end{array}$ \\
\hline
\end{tabular}

typical in military operations where the objects to be identified are items in the enemy's arsenal, infrastructures, and like things, intentionally camouflaged. Enhancement of the target image is accomplished by way of taking the raw image apart and stripping it of components that could not perceivably be part of the object whose presence is suspected. Success may be measured by, for example, the intensity of secondary explosions under attack.

\section{No a priori fixed shapes or dimensions}

This is typical in ecological studies. The object to be revealed is some unspecified regularity. "Noise" takes on

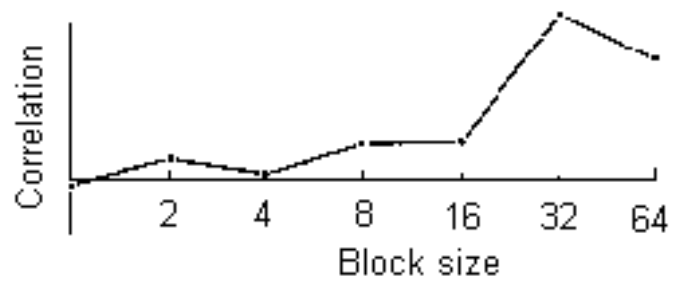

Figure 6. Kershaw's correlation/block size graph. forms that cannot be just simply identified and repealed. What should be a measure of success under these circumstances? It may be nothing more elaborate than a definite sense that the outcome is consistent with facts and reason. A very simple example is Kershaw's correlation/block size graph (Figure 6). From the simple graph one is justified to draw the remarkable conclusion that soil depth has multi-scale effect upon species pattern. Effect peaks at block size 32 in this blocking scheme.

State variables, scale variables

Pattern is described by its state variables and scale variables. State variables are primary variables such as species performance, or functions of primary variables such as entropy. Scale variables have to do with sampling unit size, embedding dimension, redundancy, tolerance limit, etc. Table 4 contains examples.

\section{Trajectory mapping}

I am considering next the description of vegetation pattern dynamics known to the phytosociologist as "synmorphogenesis". This dynamics is perceivable as a trajectory through time, at each point of which is located a past state of pattern in nature. Although states are arranged in 
the continuity of time, in practice the states of pattern are described at discrete time points, like at specific depths in the pollen-bearing sediment, and around a set of isolated points in the landscape from where the paleopollen or other time series data originate.

Figure 7 shows the phase space mapping of an idealised trajectory at a single landscape point. The axes represent state variables $X_{1}, X_{2}, \ldots, X_{p}$. The trajectory line is the time-dimension. The apices (points on the connected straight lines) represent past vegetation states. I use "paleorelevé" to designate the record set $\left(X, X_{2} \ldots X_{p}\right)$ that fixes a vegetation state as a point in phase space directly or through some transformation such as in components analysis (Orlóci 1978). The zigzag line is intended to indicate synmorphogenesis infested with the seeds of chaos, the sources of unpredictability. Chaotic oscillations are superimposed on an imaginary Markov chain (connected straight lines in Figure 7), intended to indicate the type of determinism expected under ideal conditions. In fact, under this expectation the process moves rapidly at the beginning, indicated by long inter-point distances, and then it slows down gradually. At one uncertain point in time, cumulative effects bearing down upon the transition probabilities gain sufficient momentum to cause the process to change its direction. The greater is the cumulative effect, the sharper the directional change.

Note that the phase space shown in Figure 7 is linear. Because of this, the curvier the trajectory's mapping, the higher the level of non-linearity in the process. The complex of conditions that limit the trajectory to a specific compartment of phase space is called the attractor (A).

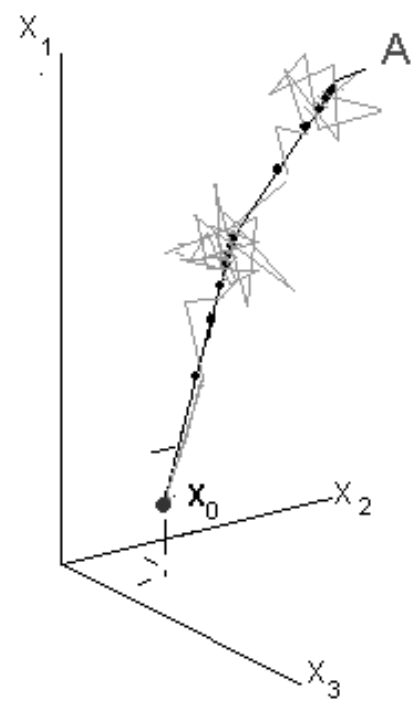

Figure 7. Sketch of an idealised process trajectory in phase space, showing a chaos infested deterministic process.

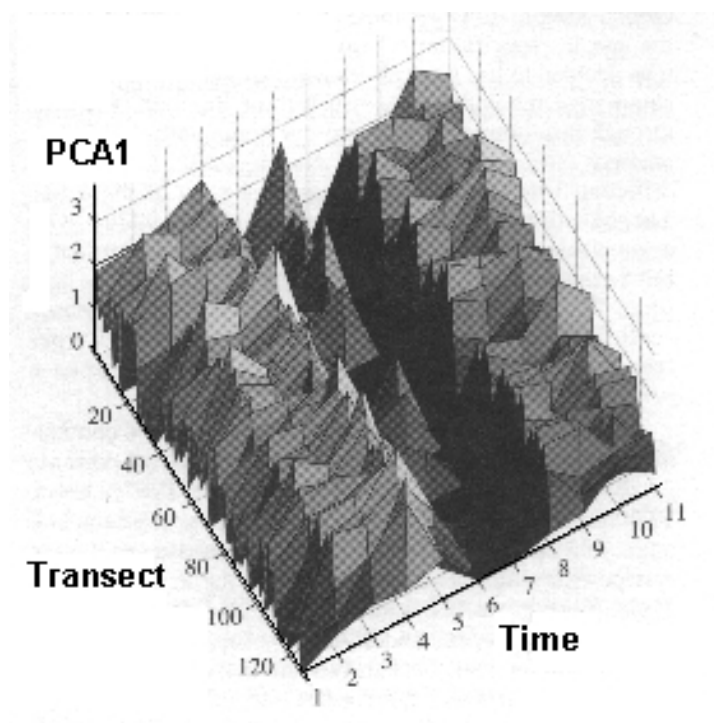

Figure 8. Anand-Kadmon graph of periodic change in vegetation along transect in the Sinai desert $30^{\circ} 56^{\prime} \mathrm{N} ; 34^{\circ}$ 23 'E. Graph dimensions as labelled.

Figure 7 displays the graph of a trajectory that originates from one point in the landscape. In spatial pattern analysis, many trajectories have to be handled simultaneously that originate from neighbouring points, forming a trajectory surface. The Anand and Kadmon 2000) trajectory set in Figure 8 is of this kind.

\section{Analysis of pattern dynamics}

\section{The data}

The analysis of pattern dynamics requires site-specific data. Typical data types include records of permanent plots (e.g., Table 3), paleopollen spectra (Figure 1), or surrogate time-series constructed in the manner of space-for-time substitutions simply like Kerner's (1863) use of this technique, or more sophisticated like the case that Wildi and Schütz (2000) describe. The data sources of the Essay are identified in Table 5.

\section{Outstanding questions, some technical tasks}

Concrete manifestations of pattern dynamics are found in the morphology of the trajectory's graph in phase space mapping. Three questions come to mind that a study of pattern dynamics should attempt to answer:

(a) What was the past pattern like? (b) What made it evolve into the state actually observed? (c) In what kind of state will pattern exist at some future point in time? 
Table 5. Site locations and other information about data in the examples.

\begin{tabular}{lcccl}
\hline Location & Latitude & $\begin{array}{l}\text { Longi- } \\
\text { tude }\end{array}$ & $\begin{array}{l}\text { Period } \\
\text { length (K) } \\
\text { years) }\end{array}$ & $\begin{array}{l}\text { Contact } \\
\text { person or } \\
\text { referee }\end{array}$ \\
\hline $\begin{array}{l}\text { Jackson Pond, Kentucky, } \\
\text { U.S.A. }\end{array}$ & $37^{\circ} \mathrm{N}$ & $85^{\circ} \mathrm{W}$ & 20.5 & G. R. Wilkins \\
$\begin{array}{l}\text { Lagoa das Patas, } \\
\text { Amazonas }\end{array}$ & $0 \circ \mathrm{N}$ & $67^{\circ} \mathrm{W}$ & 42.2 & $\begin{array}{l}\text { P.E. De } \\
\text { Oliviera }\end{array}$ \\
$\begin{array}{l}\text { Atlantic Heathland, } \\
\text { Holland }\end{array}$ & $52^{\circ} \mathrm{N}$ & $6^{\circ} \mathrm{E}$ & 0.019 & $\begin{array}{l}\text { Lippe et al.. } \\
\end{array}$ \\
& & & & 1985 \\
\hline
\end{tabular}

Three broad categories of technical tasks loom high, arising from these questions, in addition to the acquisition of a suitable data set:

(a) Mapping the trajectory into phase space .(b) Description of trajectory morphology. (c) Epidemiology, i.e., the identification of causal mechanisms, etc.

Phase space axes are conveniently constructed in component analysis. Eigenanalysis, the algebraic core of component analysis, is the better term to use here. Why? - because of the connotations from statistics that component analysis does have, but irrelevant in analytical manoeuvres whose only objective is to create a parsimonious reference system for trajectory mapping. Eigenanalysis does exactly this, passing from the original linearly correlated variables of the raw data to linearly independent (orthogonal) synthetic variables that then can be used for phase space co-ordinates. Reference is made to Orlóci (2000 and references therein) for other details.

It is true, as S. Bartha writes in his review of the Essay, that the structure of the phase space is very sensitive to the actual species composition and to sampling/scaling errors. He suggests as a remedy the Juhász-Nagy method (cf. Table 4) which uses "state space" structures, possibly steps removed from the actual field data. Bartha sees an advantage in this amounting to direct comparability of trajectories of very different origin. It will be seen in the sequel that trajectory comparison can be freed from the mentioned constraints by other a posteriori manipulations.

\section{Characterisation of the dynamic process}

What remains for the Essay to cover in the allotted space is a closer characterisation of the dynamic process. Since the trajectory's morphological characteristics are the basis of this, the characterisation is that of synmorphogenesis. The characteristics that appear to define broad classes, within which all descriptors could be accommo-

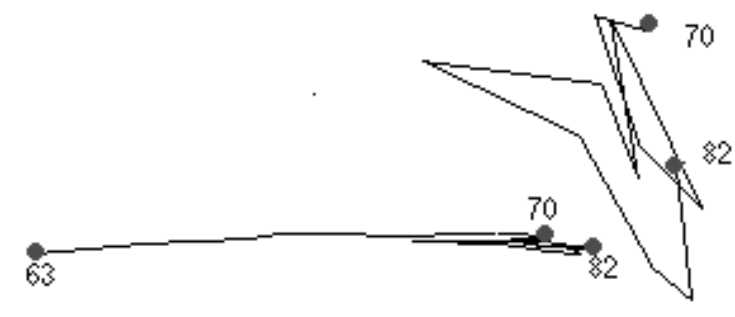

Figure 9. Eigenmapping of the Atlantic Heathland trajectory based on the data in Table 3. Left graph: map of total period length at uniform scale. Right graph: enlargement of last 12 years, distorted to show more details. $99 \%$ of total variation in the data is retained in the Eigenmap.

dated, include phase-structure, determinism, dimensionality, periodicity, attractor movement, and parallelism.

\section{Phase-structure}

The case to be discussed uses the data set from Table 3 . The trajectory mapping is seen in Figure 9. First inspection reveals a definite two-phase process: an early linear phase (1963-1970) followed by an intensely turbulent phase (1970-82). The latter begins with occlusion in the form of carrying capacity suddenly put in the way of the process (see Orlóci and Orlóci 1988, Anand and Orlóci 1997, Orlóci 2000). A striking feature, similar to the random-perturbed Markov chain (Figure 5), is the reappearance of bursts of linear motion (more or less straight line multipoint segments in map) between sharp directional turns. But the process plays itself out within the confines of an ecological attractor that does not allow the trajectory to develop in the manner of a pure Brownian model.

\section{Determinism}

When the trajectory has directed components, more or less straight multi-point line segments, like in Figure 9, the term "determinism" is appropriate to characterize it. 
Table 6. Trajectory determinism, measured as a rank correlation of distance structures. RND designates a simulated trajectory based on the assumption that vegetation dynamics generates random compositional transitions (see Orlóci 2000). In this sense RND trajectory is a random permutation of the observed vegetation states. Expectations and probability $(\mathrm{P})$ values were determined based on 1000 RND trajectories. P expresses the probability of an at least as large correlation value as the observed, occurring under random compositional transitions.

\begin{tabular}{lcccc}
\hline \multicolumn{1}{c}{ Site } & Observed & \multicolumn{2}{c}{ Expectations of } & $\mathrm{P}$ \\
& correlation & correlation & variance & \\
\hline Lagoa das Patas & 0.458 & 0.001 & 0.000313 & $<0.001$ \\
Jackson Pond & 0.769 & 0.017 & 0.000732 & $<0.001$ \\
Atlantic Heathland 19 yrs & 0.500 & 0.000 & 0.006030 & $<0.001$ \\
$\begin{array}{l}\text { Atlantic Heathland, first 7 } \\
\text { yrs }\end{array}$ & 0.966 & 0.000 & 0.054900 & $<0.001$ \\
Atlantic Heathland, last & 0.058 & 0.001 & 0.015200 & 0.318 \\
12 yrs & & & & \\
RND & -0.002 & -0.001 & 0.005776 & 0.496 \\
\hline
\end{tabular}

Determinism implies that the attractor conditions in the site are forcing the process on a short path ever closer in the direction of the target. The target, a potential vegetation state, may change before it is reached.

Representation of the attractor as a single point (A in Figure 2) is, of course, not quite correct. The attractor should rather be conceived as a point oscillating within a region in phase space to which it is confined by ecological laws. The notion of the attractor as potential vegetation, the type that could be reasonably expected in a site under natural circumstances, is quite familiar, not necessarily under the same name, to cartographers of the vegetation (see Küchler 1990).

There are different ways to depict determinism. Some methods are qualitative while others are quantitative. Two examples should clarify this point:

a. Qualitative method. A vegetation type from the region is selected that fits the phytosociologist's reasoned criteria of the vegetation attractor's state. In the St. Lawrence lowlands, for example, the attractor state is considered to be an Aceretum. In Dansereau's (1957, p. 175) scheme, the Aceretum can develop through an allogenic hydrosere or autogenic xerosere. Considering Dansereau's xerosere, it begins with an Oenotheretum that gives way to Danthonietum $\rightarrow$ Festucetum $\rightarrow$ Solidaginetum $\rightarrow$ Crataegetum $\rightarrow$ Pinetum $\rightarrow$ Aceretum. The xerosere is a perception based on Kernerian space-for-time substitutions. The reoccurrence of the same vegetation sere in different sites in the region is offered as evidence that the sere depicted a universal tendency in community development towards the Aceretum. There could be, of course, other attractor states identified locally, say a Pinetum, Pineto-Picetum, or all together something else, to which the Oenotheretum sere may be tending with varying probability. The higher is this probability for a specific sere, the more determined is the long-term direction of the Oenotheretum.

b. Quantitative method. While the qualitative method is definitely predictive, the quantitative method to be described is definitely postdictive. It answers the question "how smoothly a trajectory (temporal coenosere) has run its course up to a selected time point". If there is much turbulence, directionless movement, determinism will be undermined. If it is smooth sailing right through, the appearance of determinism will be enhanced. Of the many methods available to measure determinism, two are selfevident: "autocorrelation" and "matching-structures correlation". I consider the latter. I use the rank correlation coefficient, symbolically $r\left(\boldsymbol{D}_{c} ; \boldsymbol{D}_{t}\right)$, as my scaler. The elements of $\boldsymbol{D}_{c}$ are the compositional distances of paleorelevès (paleocoenostates). The elements of $\boldsymbol{D}_{t}$ are the same paleorelevés' chronological differences. All distinct comparisons are made, $n(n-1) / 2$ in total. The number of paleorelevès is $n$. Actual correlation values are given in Table 6 .

Inspection of Table 6 reveals that in the RND case and within the turbulent phase, such as in the Atlantic Heathland trajectory during the last 12 years, determinism all but vanishes. The trajectories of Lagoa das Patas and Jackson Pond, and the first phase of the Atlantic Heathland trajectory incorporate statistically significant and in two cases numerically very high linear determinism.

\section{Dimensionality}

The dimension of a trajectory can be the number of taxa, a lesser number that counts the non-zero Eigenvalues, or something else that is not even an integer number. A specific case from the family of fractals helps to make some interesting points. The source reference is Mandelbrot 


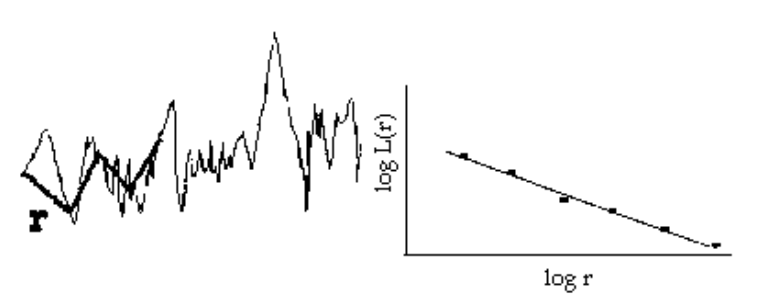

Figure 10. Determination of a length-related fractal dimension $D$ of an irregular line. The fractal dimension in this case is approximately 0.642. See Scheuring (1993) and the main text for details.

(1967, 1977). A good reference for technique is Schroeder (1991).

What did Mandelbrot do? He was interested in irregular and fragmented shapes - like Perrin's Brownian trajectory, the perimeter of a soap flake, or the coastline of Britain - and developed a new geometry that helped him to describe these. At the core of Mandelbrot's scheme is the relation $L(r)=L_{O} r^{1-D}$ or $L(r) \sim r^{1-D}$. In this, $L(r)$ is length measured with calliper width set at $r$ and $D$ is the length-related fractal dimension. When shape is invariant, that is to say, when no new detail is gained or detail lost under changing magnification, $L_{O}=L(r)$ and $D=1$.

One method that helps to approximate the value of $D$ relies on the regression coefficient $b$ which is related to $D$ in the manner of $b=1-D$. The regression line is the best fitting straight line through the point swarm $\{\log L(r), \log$ $r$ ) over a wide range of $r$ values. I selected an example from Scheuring's (1993) to illustrate this (Figure 10). To the reader, fractal dimension need not mean anything more complicated than a decimal number, such as 0.642 in Figure 10.

Another kind of fractal dimension is the so-called correlation dimension $D_{2}$ which I use in trajectory description and about which my terminology follows, in part, Schroeder (1991, pp. 220-224). The example to be presented is taken from Orlóci (2000). The regression coefficient $b$ gives a direct approximation of $D_{2}$. The regression set-up is shown in Figure 11a. The trajectory involved is computed from the Lagoa das Patas paleopollen spectrum. Variable $r$ represents, in turn, the Euclidean distance, I-divergence information, or inner angle for pairs of paleorelevé vectors. $C(r)$ is the relative frequency of $r$ in a $q x q$ matrix. Symbol $q$ is the number of a

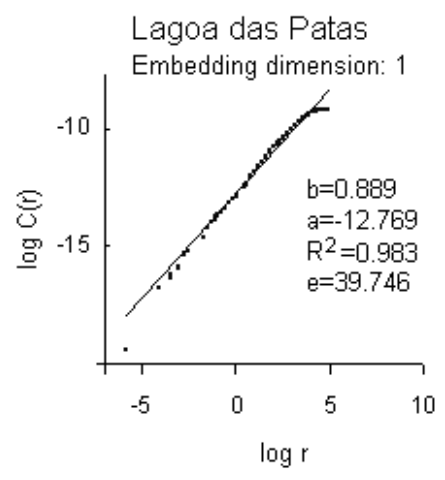

b
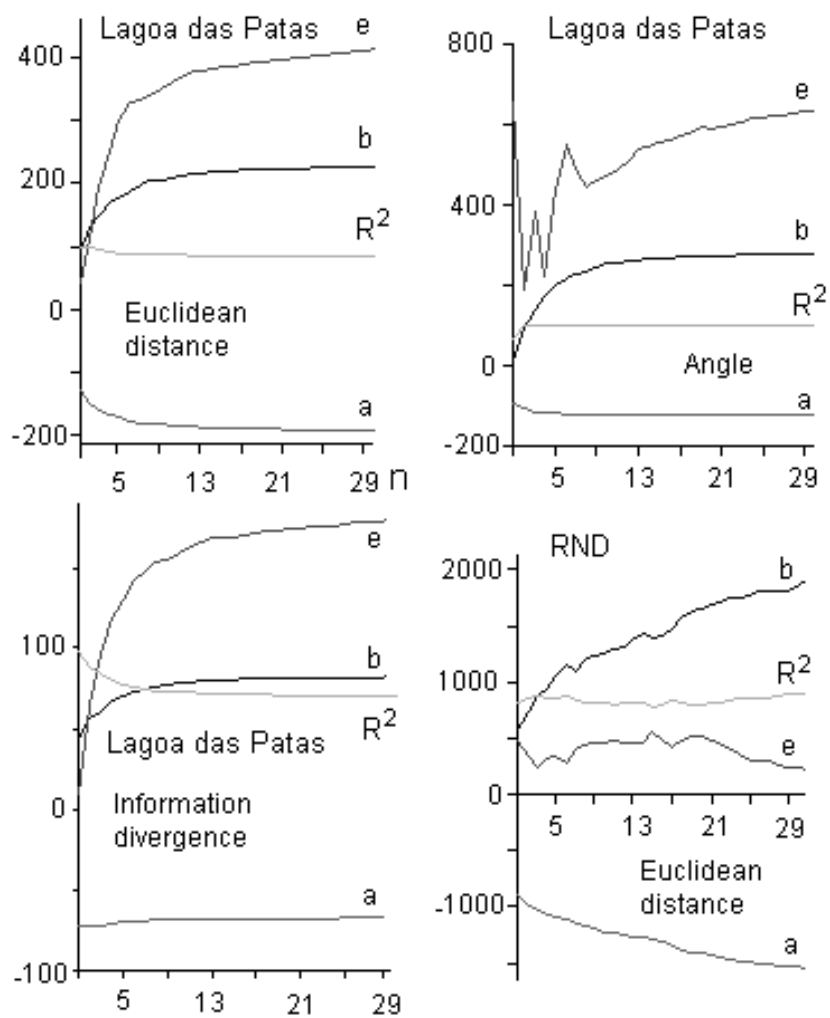

Figure 11. States of trajectory descriptors in relation to embedding dimension $n$. See Orlóci (2000) for details. a: $r$ and $C(r)$ - descriptor variable (distance, information, or angle) and its relative frequency; $b, a, R^{2}, e$ - regression coefficient $\left(D_{2}\right)$, intercept, coefficient of determination, and the error term. b: values of the above over embedding dimension. A descriptor's value at which its graph starts levelling off is a fractal dimension of the trajectory. 
Table 7. Conditions at the lower latitude/elevation limit of vegetation zones as identified. Data and method after Orlóci (1994). Values underlined are extrapolations based on TFR $=-2.57538+0.12749 X$. Variable $X$ is the decimal equivalent of a locality's northern latitude. The value of the coefficient of determination is 0.97 . Regression is based on the data from the first 5 sites in the table. Abbreviations: Prec. - mean precipitation; Temp. - mean annual temperature; LTFR - local thermal flux rate; LTRI - local temperature increase; ELT - expected local mean annual temperature. All temperatures are given in Celsius degrees. Data in rows 3, 4 are from Walter et al. (1975), except the last two columns that were obtained from Krajina (1963).

\begin{tabular}{|c|c|c|c|c|c|c|c|c|}
\hline & & $\begin{array}{r}\text { Arctic } \\
\text { Tundra }\end{array}$ & $\begin{array}{l}\text { Boreal } \\
\text { Forest }\end{array}$ & $\begin{array}{r}\text { Mixed } \\
\text { Conifer- } \\
\text { Northern } \\
\text { Hardwod } \\
\text { Forest } \\
\end{array}$ & $\begin{array}{r}\text { Cool } \\
\text { Temperate } \\
\text { Deciduous } \\
\text { Forest }\end{array}$ & $\begin{array}{r}\text { Warm } \\
\text { Temperate } \\
\text { Evergreen } \\
\text { Forest }\end{array}$ & $\begin{array}{r}\text { Tropical } \\
\text { Alpine } \\
\text { Tundra } \\
(3,300 \mathrm{~m})\end{array}$ & $\begin{array}{r}\text { Tropical } \\
\text { Subalpine } \\
\text { Scrubland } \\
(2,000 \mathrm{~m})\end{array}$ \\
\hline 1 & $\begin{array}{l}\text { Climatic } \\
\text { station }\end{array}$ & $\begin{array}{r}\text { Port } \\
\text { Harrison, } \\
\text { Quebec }\end{array}$ & $\begin{array}{r}\text { Timmins, } \\
\text { Ontario }\end{array}$ & $\begin{array}{r}\text { Stratford, } \\
\text { Ontario }\end{array}$ & $\begin{array}{l}\text { Nashville, } \\
\text { Tennessee }\end{array}$ & $\begin{array}{r}\text { Mobil, } \\
\text { Alabama }\end{array}$ & \multicolumn{2}{|c|}{$\begin{array}{c}\text { Mauna Kea, } \\
\text { Hawaii }\end{array}$} \\
\hline 2 & N. latitude & $58^{\circ} 26^{\prime}$ & $48^{\circ} 31^{\prime}$ & $43^{\circ} 22^{\prime}$ & $36^{\circ} 10^{\prime}$ & $31^{\circ} 42^{\prime}$ & $19^{\circ} 49^{\prime}$ & $19^{\circ} 49^{\prime}$ \\
\hline 3 & Prec. mm & 372 & 711 & 773 & 1,144 & 1,439 & 510 & 1020 \\
\hline 4 & Temp. & -7.5 & 1.3 & 8.3 & 15.6 & 19.8 & 0 & 4.4 \\
\hline 5 & LTFR & $\underline{4.9}$ & 3.7 & 2.8 & 2.1 & $\underline{1.5}$ & 1.8 & 1.8 \\
\hline & LTRI & 12.3 & 9.2 & 7.0 & 5.3 & 3.8 & 4.5 & 4.5 \\
\hline 7 & ELT & 4.8 & 10.5 & 15.3 & 20.9 & 23.6 & 4.5 & 8.9 \\
\hline
\end{tabular}

paleorelevés, and $n$ is an embedding dimension (Figure $11 b)$. The embedding dimension in the example is a count of the phase space axes, so that $n=1,2,3, \ldots$. The consequences of order in which the axes are counted is discussed by Orlóci (2000).

It is quite obvious that different structures can have intense self-similarity. This is seen in the shape of the respective graphs, that is, in the tendency to level off past some critical embedding dimension. The same structures do not show self-similarity with the RND trajectory. The RND trajectories are constructed on the basis of the assumption that the process is ruled by random compositional transitions.

Self-similarity in the manner of the example implies redundancy of taxa. Interesting to mention the suggestion that the DNA sequence of the chromosome does does not have self-similarity. If true, it should imply high parsimony of the genetic code, in a very mechanistic sense.

\section{Attractor migration}

The Delcourt and Delcourt (1985) diagram, reproduced in Figure 2, provides us with a real example of attractor migration on the continental scale. Migration at this scale is forced by climate change, and broad vegetation shifts are the result. The velocity of shifts in temporal or geographic terms, taking the period from 14 to 6 thousand years before present as an example, is $300 \mathrm{~km} / 1000$ years or 600 $\mathrm{km}$ per one degree Celsius rise in the global average temperature. What kind of thermal flux rates could possibly cause the persistent and sometimes violent changes? Table 7 displays estimates.

\section{Periodicity}

Compositional entropy and process velocity are two examples of variables undergoing irregular periodic change. Figure 12 gives the relevant graphs for Atlantic Heathland and Lagoa das Patas (after Orlóci 2000). Periodicity is not haphazard. In fact, this is quite apparent on first inspection of the graphs. Entropy and velocity are inversely related. In the Atlantic Heathland, entropy drops to the lowest point after the onset of logistic occlusion around 1973. Entropy is high following fire around 1963 and after a short drought period around 1977. In Lagoa das Patas, entropy appears to increase during global cooling and decrease when the climate is warming. Another representation of cyclic change, as in Figure 8, combines the spatial dimension of change with the temporal.

\section{Parallelism}

The idea that there is a tendency toward global parallelism of paleopollen spectra comes from van Post (1946). The example in Figure 13 takes the van Post suggestion a step further in a significant way. For worked example and algorithmic references, the reader is directed to Orlóci (2000, He and Orlóci 1998).

Three trajectories are compared: Lagoa das Patas (LdP), Jackson Pond (JP), and a random trajectory (RND) in Figure 13a, and random vs. random in Figure 13b. The RND trajectories are constructed as explained above. The 

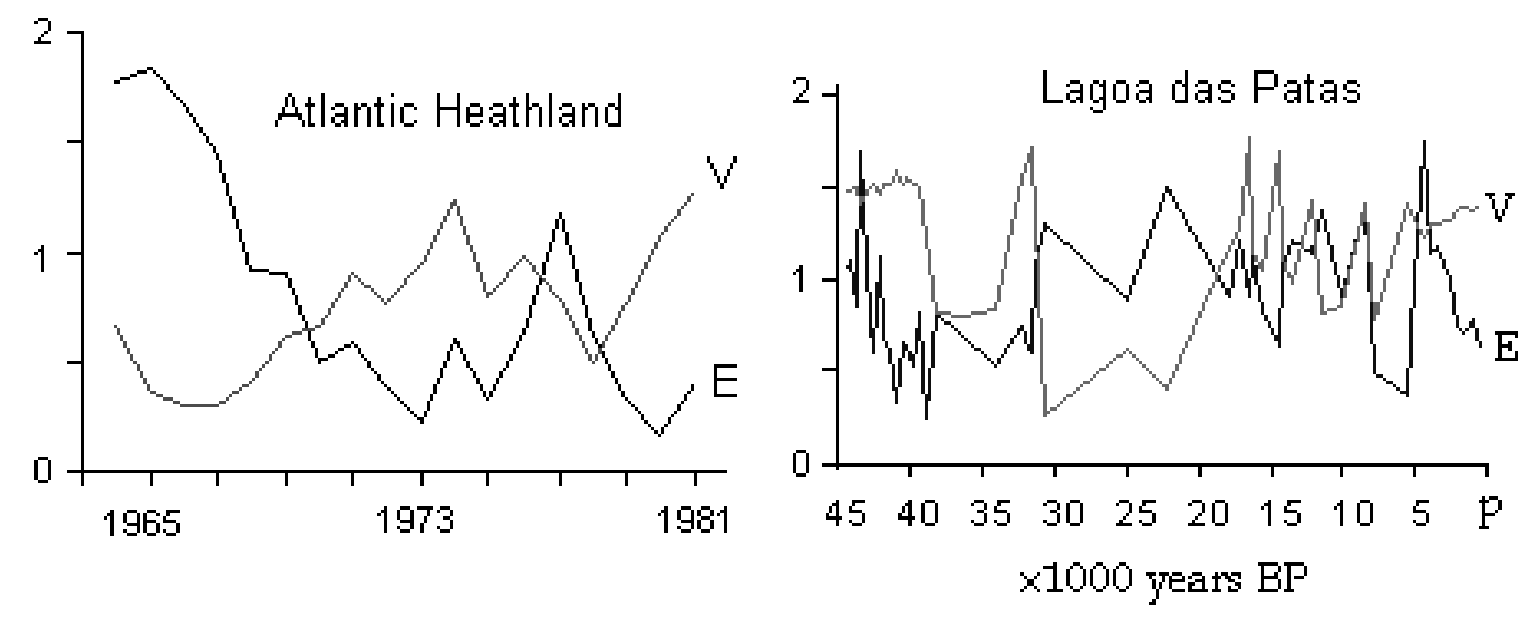

Figure 12. Evolution of compositional entropy in relation to process velocity at two sites.

a
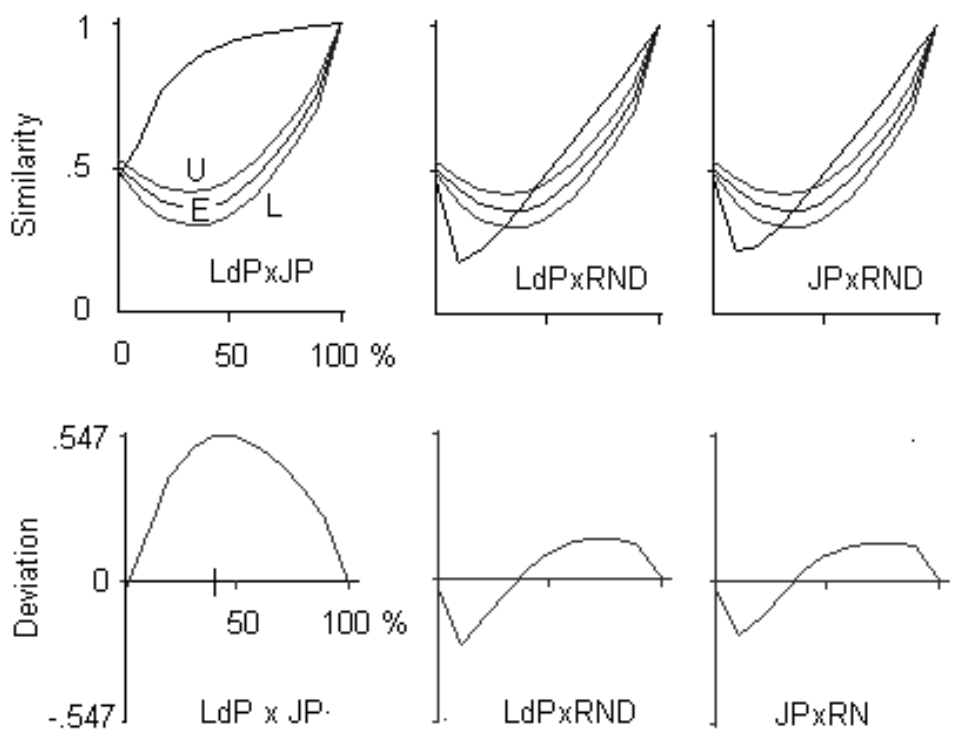

b

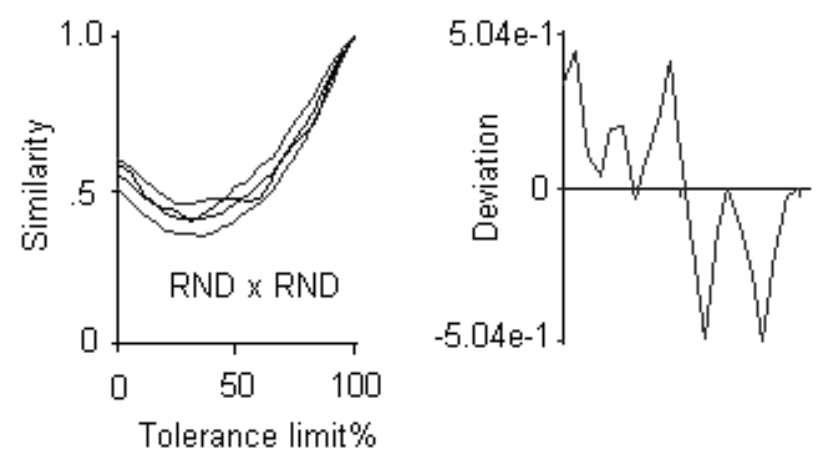

Figure 13. Trajectory parallelism. See details in the text and detailed explanations in Orlóci (2000). 
top (unlabelled) curve in first row of first graph in Figure 13a displays the similarity of trajectories LdP and JP in relation to given tolerance limits. Tolerance limits, an engineering concept and not the same as the statistical confidence limits (see Orlóci 2000, for explanation), compensate for the uncertain position of trajectory points in phase space on the count of stochastic variation. Tolerance limits are arbitrarily expanded in small steps. As for the other curves in the first graph, label E identifies expected values, $U$ the upper bound, and $\mathrm{L}$ the lower bound of the $95 \%$ statistical confidence interval. The graphs in Figure 13b are interpreted the same way. It is immediately obvious that the similarity curve in Figure $13 \mathrm{~b}$ runs completely within the confidence limits. This is to be expected, considering that RND trajectories cannot be parallel.

Parallelism in any trajectory pair can be characterised by the entire similarity graph. Only graph portions outside the confidence limits are considered statistically significant. The maximum level of parallelism is proportional to the similarity value where it deviates most from random expectation. The curves in the second row of Figure 13a show the deviations.

\section{Closing remark}

In the Essay I described briefly my understanding of the concept "pattern" and the study scenario that I would see fit to follow in pattern analysis. I defined an ecological pattern universe whose main characteristics are object fuzziness, chaos-infested determinism, and scale dependent perception. In my scheme, descriptions of momentary pattern states provide input into the construction of process trajectory mappings. I used the characteristics of the trajectories to describe synmorphogenesis at given landscape points. These descriptions lay foundations for tracing pattern dynamics by establishing connections between trajectories from neighbouring landscape points. I brought up the question of pattern epidemiology, but I leave the detailed exploration of this topic for a more adventurous reader.

Acknowledgements. I thank Enrico Feoli and Elisa De Roa for hospitality at the UNIDO-ICS workshop, Guillermo Goldstein for welcoming me back to his lab at the university of Hawaii at Manoa where the manuscript was completed, and Márta Mihály for help with editing and revisions. It is a further pleasure for me to thank Sándor Bartha and István Scheuring for valuable comments.

\section{References}

Anand, M. and L. Orlóci. 1997. Chaotic dynamics in multispecies community. Env. Ecol. Stat. 4: 337-344.

Anand, M. and R. Kadmon. 2000. Community-level analysis of spatiotemporal plant dynamics. Ecoscience 7:101-110.
Anand, M., and L. Orlóci. 2000. On hierarchical partitioning of an ecological complexity function. Ecol. Model. 132:51-62.

Bartha, S., T. Czárán, and J. Podani. 1998. Exploring plant community dynamics in abstract coenostate space. Abstr. Bot. 22:49-66.

Bartlett, M. S. 1975. The Statistical Analysis of Spatial Pattern. Chapman and Hall, London.

Connell, J.H. and R.O. Slatyer. 1977. Mechanisms of succession in natural communities and their role in community stability and organization. Amer. Nat. 111: 1119-1144

Dansereau, P. 1957. Biogeography. An Ecological Perspective. Ronald Press, New York.

Darwin, C. 1859. On the Origin of Species. Murray, London.

Delcourt, P.A. and H.R. Delcourt. 1987. Long-term Forest Dynamics of the Temperate Zone. Springer, New York.

Egler, F.E. 1954. Vegetation science concepts. I. Initial floristic composition - a factor in old-field vegetation development. Vegetatio 4: 412-417.

Fekete, G. and Z. Fekete. 1998. Distance distribution between patch systems: a new method to analyse community mosaics. Abstr. Bot. 22: 29-35.

Feoli, E. and V. Zuccarello. 1988. Syntaxonomy: a source for useful fuzzy sets for environmental analysis? Coenoses 3: 141-147.

Greig-Smith, P. 1952. The use of random and contiguous quadrats in the study of the structure of plant communities. Ann. Bot., London 16:293-316.

Greig-Smith, P. 1983. Quantitative Plant Ecology. 3rd ed. Blackwell, London.

Grime, J.P. 1977. Evidence for the existence of three primary strategies in plants and its relevance to ecological and evolutionary theory. Amer. Nat. 111: 107-1169-1194.

Harper, J.L. 1977. Population Biology of Plants. Academic Press, London.

He, X. and L. Orlóci. 1998. Anderson pond revisited: the late-Quaternary vegetation process. Abstr. Bot. 22: 81-93.

Kerner von Marilaun, A. 1863. Das Pflanzenleben der Danauländer. Innsbruck, Wagner.

Kershaw, K.A. 1973. Quantitative and Dynamic Plant Ecology. 2nd ed. Edward Arnold, London.

Krajina, V. J. 1963. Biogeoclimatic zones on the Hawaiian Islands. Newsletter of the Hawaiian Botanical Society 7:93-98.

Küchler, A.W. 1990. Natural vegetation. In: E.B. Espenshade and J.L. Morrison (eds.), Goode's World Atlas, 18th ed. Rand McNally, Chicago. pp. 16-17.

Lippe, E., De Smidt, J.T and D.C. Glen-Lewin. 1985. Markov models and succession: a test from a heathland in the Netherlands. $J$. Ecol. 73: 775-791.

Mandelbrot, B.B. 1967. How long is the coastline of Britain? Statistical self-similarity and fractal dimension. Science 156:636-638.

Mandelbrot, B.B. 1977. Fractals. Form, Chance, and Dimension. Freeman, San Francisco.

May, R.M. 1976. Simple mathematical models with very complicated dynamics. Nature 261: 459-471.

May, R.M. and G.F. Oster. 1976. Bifurcations and dynamic complexity in simple ecological models. Amer. Nat. 110:573-599.

Milankovitch, M.M. 1941. Canon of isolation and the Ice-Age problem. Royal Serb Academy Special Publication 133.

Mueller-Dombois, D. 1992. A natural dieback theory, cohort senescence, as an alternative to decline disease theory. In: P.D. Man- 
ion and D. Lachance (eds.), Forest Decline Concepts. The Am. Phytopath. Soc., St. Paul, Min. pp. 26-37.

Orlóci, L. 1971. An information theory model for pattern analysis. $J$ Ecol. 59: 343-349.

Orlóci, L. 1978. Multivariate Analysis in Vegetation Research. 2nd ed. W. Junk, The Hague.

Orlóci, L. 1994. Global warming: the process and its phytoclimatic consequences in temperate and cold zone. Coenoses 9: 69-74.

Orlóci, L. 2000. From Order to Causes. A personal view, concerning the principles of syndynamics. Internet edition. http://sites.netscape.net/lorloci

Orlóci L., Anand, M. and X.S. He. 1993. Markov chain: a realistic model for temporal coenosere? Biometrie-Praximetrie 33: 7-26.

Orlóci, L and V. De Patta Pillar. 1991. On sample size optimality in ecosystem survey. In: Feoli, E. and L. Orlóci (eds.), Computer Assisted Vegetation Analysis, Kluwer, Dordrecht. pp. 41-46.

Orlóci, L. and M. Orlóci. 1988. On recovery, Markov chains, and canonical analysis. Ecology 69: 1260-1265.

Perrin, J. 1913. Les Atoms. Alcan, Paris. (English transition 1919, Van Nostrand, New York.

Pielou, E.C. 1964. The spatial pattern of two-phase patchworks of vegetation. Biometrics 20:156-167.

Pielou, E.C. 1977. Mathematical Ecology. Wiley, New York.

Podani, J., T. Czárán, and S. Bartha. 1993. Pattern and diversity: the importance of spatial scale. Abstr. Bot. 17:37-51.
Poore, M.E.D. 1955a,b. The use of phytosociological methods in ecological investigations. J. Ecol. 43: 245-69, 606-51.

Post, L. Von. 1946. The prospect for pollen analysis in the study of the earth climatic history. New Phytol. 45: 193-217.

Rényi, A. 1961. On measures of entropy and information. In: J. Neyman, ed., Proceedings of the 4th Berkeley Symposium on Mathematical Statistics and Probability, pp. 547-561. University of California Press, Berkeley.

Scheuring, I. 1993. Multifractality - a new concept in vegetation science. Abstr. Bot. 17: 71-77.

Schroeder, M. 1991. Fractals, Chaos, Power Laws. Freeman, New York.

Tucker, C.J., J.R. Townshend, and T.E. Goff. 1985. African landcover classification using satellite data. Science 227:369-375.

Walter, H., E. Harnickell, and D. Mueller-Dombois. 1975. Climatediagram Maps. Springer -Verlag, New York.

Watt, A.S. 1947. Pattern and process in the plant community. J. Ecol. 35:1-22.

Wildi, O. and L. Orlóci. 1991. Flexible gradient analysis: a note on ideas and an application. In: E. Feoli and L. Orlóci (eds.), Computer Assisted Vegetation Analysis, Kluwer, Dordrecht. pp. 249254.

Wildi, O. and M. Schütz. 2000. Reconstruction of a long-term recovery process from pasture to forest. Community Ecol. 1:25-32. 